Keywords:

Bio-oil

Bio-based resin

Bond strength

Pyrolysis

Wood

Historic:

Received 26/04/2017

Accepted 24/I I/2017

Palavras chave:

Bio-óleo

Resina Bio-Base

Força de ligação

Pirólise

Madeira

+Correspondence: nadiray@istanbul.edu.tr

\section{TECHNOLOGICAL PROPERTIES OF PLYWOOD BONDED WITH PHENOL- FORMALDEHYDE RESOL RESIN SYNTHESIZED WITH BIO-OIL}

ABSTRACT: In this study, it was aimed to use of bio-oil as an alternative to petroleum-based phenol in the production of phenol-formaldehyde (PF) resin used for making exterior plywood. Bio-oil obtained from pine wood sawdust using a vacuum pyrolysis reactor at $500{ }^{\circ} \mathrm{C}$. The PF resol resins were produced by substituting up to $20 \mathrm{wt} \%$ of phenol with bio-oil by modifying the chemical synthesis process. FT-IR analysis was performed to characterize the organic functional groups in the bio-oil modified PF resins. In comparison to the commercial and lab-made PF resins, the bio-oil modified PF resins were found to have larger average molecular weights, higher polydispersity indices, and shorter gel times. Six different types of plywood panels were produced from the experimental PF resins which were commercial $\mathrm{PF}$ resin, lab-made $\mathrm{PF}$ resin, and $\mathrm{PF}$ resins modified with bio oil of $5,10,15$ or $20 w t \%$ contents, respectively. Plywood specimens produced with the PF resin modified with bio-oil up to $20 \mathrm{wt} \%$ had better tensile shear strength (wet condition), modulus of rupture, and modulus of elasticity in bending as compared to the commercial and lab-made PF resins.

\section{PROPRIEDADES TECNOLÓGICAS DE COMPENSADO DE MADEIRA COLADA COM RESINA DE RESOL FENOL-FORMALDEÍDO SINTETIZADA COM BIO-ÓLEO}

RESUMO: Neste estudo, teve como obejtivo usar o bio-óleo como alternativa ao fenol à base de petróleo na produção de resina de fenol-formaldeído (PF) utilizada na fabricação de compensado exterior. $\mathrm{O}$ bio-óleo obtido a partir de serragem de madeira de pinho usando um reator de pirólise a vácuo a $500^{\circ} \mathrm{C}$. As resinas de resina $\mathrm{PF}$ foram produzidas substituindo até $20 \%$ de em peso de fenol com bio-óleo, modificando o processo de síntese química. A análise FT-IR foi realizada para caracterizar os grupos funcionais orgânicos do bio-óleo pelas resinas PF. Em comparação com as resinas de PF comerciais e feitas em laboratório, as resinas de PF modificadas com bio-óleo apresentaram pesos moleculares médios maiores, índices de polidispersão mais altos e tempos de gel mais curtos. Seis diferentes tipos de painéis de compensado foram produzidos a partir das resinas PF experimentais que eram resina PF comercial, resina PF feita em laboratório e resinas PF modificadas com óleo biológico com conteúdo de $5,10,15$ ou $20 \%$ em peso, respectivamente. As amostras de compensado produzidas com a resina PF modificada com bio-óleo até $20 \%$ em peso apresentaram maior força de cisalhamento de tração (condição úmida), módulo de ruptura e módulo de elasticidade em flexão em comparação com as resinas PF comerciais e feitas em laboratório. 


\section{INTRODUCTION}

Phenol formaldehyde (PF) resol resins are made from formaldehyde and phenol in the presence of an acid or a basic catalyst. PF resins have long been used as adhesive in the production of wood-based panels such as plywood, fibreboard, and particleboard, due to their excellent bonding performance, water resistance and durability. More than $95 \%$ of phenol all over the world, the primary component in PF resins, is made from petroleum-derived benzene ( $\mathrm{Yl}$ et al., 20I2). Its price and availability are linked to fluctuations of petroleum price. Due to growing concern for environmental pollution, reduction of availability of fossil energy resources (petroleum and coal), and increasing prices of petroleum chemicals, researchers have focused on alternative resources to the petroleum phenol in PF resins (WANG et al., 2009; ROY et al., 2000; WANG et al., 20I I; ALMA et al., 20I I; TEJADO et al., 2007; JUNMING et al., 2010; ASLAN et al., 20I5). Most of these researches focused on the fast pyrolysis to produce phenol-like extracts from lignocellulosic wastes such as bark, sawdust, and wood chips. For example, Himmelblau and Grozdits (199I) synthesized PF resins with a phenol substitution of $50 \mathrm{wt} \%$ by bio-oil obtained from fast pyrolysis of mixed hardwoods (maple, birch, and beech). These resins showed nearly as well in making three-ply plywood of southern pine as a commercial resin. In other study, Amen-Chen et al. (2002) synthesized the bio-oil-PF with a phenol substitution of $25 \mathrm{wt} \%$ or $50 \mathrm{wt} \%$ by bio-oil from the bark of softwood and prepared oriented strandboard (OSB). They reported that three-layer panels made with resins having $50 \mathrm{wt} \%$ phenol replacement in the surface and $25 \mathrm{wt} \%$ phenol replacement in the core had mechanical properties above the requirements specified by the Canadian Standard CSA 0437.0-93 for OSB products. Substitution of $50 \mathrm{wt} \%$ of petroleum phenol by pyrolysis oils led to less crosslinked resins which was evidenced by lower dry internal bond strength, wet internal bond strength andd lower bending qualities.

Bio-oil derived from the pyrolysis of biomass is a potential phenolic substance in biomass because it has a high amount of several phenolics (NGO et al., 20l3). Pyrolysis converts biomass at temperatures around 500 ${ }^{\circ} \mathrm{C}$ in absence of oxygen to the liquid (bio-oil), gaseous and solid (char) fractions. The bio-oil is a mixture of about 20 types of major and minor organic compounds including phenols, aldehydes, alcohols and carboxylic acids, derived primarily from the lignin in the feedstock (ASLAN et al., 2015).
The aim of this work was to investigate the performance of bio-oil modified PF resol resins considered as adhesive in the production of plywood for outdoor applications. The technological properties of plywood panels produced with the PF resins modified with different amounts of bio-oil were determined and the results were compared with those of plywoods produced with commercial PF resin and laboratory-made control PF resin.

\section{MATERIAL AND METHODS}

\section{Biomass and wood veneer}

Scots pine (Pinus sylvestris L.) wood sawdust was used in this study as lignocellulosic biomass, which was one of the widespread tree species in the world. The average diameter of the biomass particles was I $\mathrm{mm}$. The sawdust was dried in an oven at $102^{\circ} \mathrm{C}$ for $12 \mathrm{~h}$ prior to use as a pyrolysis sample. Defect-free beech wood (Fagus orientalis Lipsky) veneers with dimensions of 500 $\mathrm{mm} \times 500 \mathrm{~mm} \times 1.5 \mathrm{~mm}$ were used in the production of plywood panels.

\section{Chemicals}

Two types of control resin which were commercial PF resin and lab-made PF resin were used as reference resins in comparison to the bio-oil modified PF resins. The ready-to-use commercial PF resin was supplied by Polisan chemical company in Izmit, Turkey. Lab-made PF resin and bio-oil modified PF resins were produced in the laboratory resin reactor. Bio-oil modified PF resins were synthesized by using commercial phenol (liquid) and aqueous solution of formaldehyde (37 wt\%) supplied by Gentaş chemical Company, Izmit, Turkey. The commercial $\mathrm{NaOH}$ chemical used in these experiments was purchased from distributor of Sigma Aldrich Company in Istanbul, Turkey.

\section{Production and chemical characterization of the bio-oil}

The pyrolysis of biomass conducted at a final temperature of $500{ }^{\circ} \mathrm{C}$ and a total pressure lower than $10 \mathrm{kPa}$. In the pyrolysis process, a sample of $2000 \mathrm{~g}$ was weighed and placed into the reactor, which was heated by an electric furnace. During the experiments, the heating rate and pyrolysis temperature were controlled with a Proportional-Integral-Derivative (PID) controller. The pyrolysis final temperature was set to $500{ }^{\circ} \mathrm{C}$ at a heating rate of $15^{\circ} \mathrm{C} \cdot \mathrm{min}^{-1}$ and maintained for $60 \mathrm{~min}$. After the pyrolysis was terminated, the liquid product 
was collected from the condensers. The scheme of the bench-scale vacuum pyrolysis experimental setup was given in Figure I. The chemical composition of the bio-oil was determined by GC/MS analysis. The procedure was extensively explained in previous publications (OZBAY, 20I5; OZBAY; AYRILMIS, 20I4). The data acquisition system used was GI035A software with a NIST library.

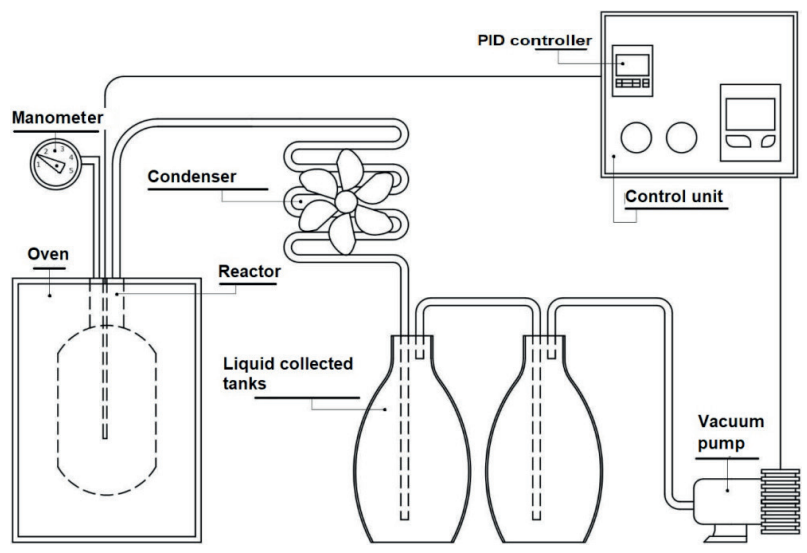

FIGURE I Scheme of the bench-scale vacuum pyrolysis experimental setup.

\section{Chemical synthesis of PF resins}

Bio-oil was used without further pre-treatment for the resin synthesis. The preparation procedure was as follows: the reactor was charged with $700 \mathrm{~g}$ of phenol, and then I I $00 \mathrm{~g}$ formaldehyde (37 wt\%) and $62.5 \mathrm{~g}$ of $\mathrm{NaOH}$ solution (50 wt\%) ( $\mathrm{I} / 3$ of total $\mathrm{NaOH}$ weight) were mixed in the resin reactor. The replacement levels of phenol by the bio-oils were 5 wt\%, 10 wt\%, 15 wt\% or 20 wt\%. The reaction temperature increased from room temperature to $60{ }^{\circ} \mathrm{C}$ within 60 minutes. The reaction mixture was heated to $90^{\circ} \mathrm{C}$ and kept at $90^{\circ} \mathrm{C}$ until dynamic viscosity of resin reached between $600-800 \mathrm{cps}$. Then the second part $\mathrm{NaOH}$ (50 wt\%) solution was added into the reactor at temperature of $60^{\circ} \mathrm{C}$. After the reaction was completed, the reactor was cooled to room temperature.

\section{Characteristics of $P F$ resins}

The $\mathrm{pH}$ of all resins was determined using a digital $\mathrm{pH}$ meter (TES-I $380 \mathrm{pH}$ meter). The $\mathrm{pH}$ value from the instrument was recorded. The dynamic viscosity of resins was measured with a rotational viscometer (Brookfield digital viscometer, model: Dv-IPrime) according to ASTM D I084-08 (2008). Measurement of solids content in the PF resin was performed according to ASTM D 3529 (2008). Gel time of the resin was measured by charging $5 \mathrm{~g}$ of resin into a test tube and heating the test tube in an oil bath at $100^{\circ} \mathrm{C}$. The elapsed time until the point when no further stirring was possible is defined as the gel time for the resin sample. FT-IR measurements were carried out in an Alpha FT-IR instrument by direct transmittance using $\mathrm{KBr}$ pellet technique. Each spectrum was recorded at a rate of 10 scans, in the range from 4000 to $400 \mathrm{~cm}^{-1}$ with a resolution of $4 \mathrm{~cm}^{-1}$.

\section{Production of plywood panels}

The plywood panels were produced under laboratory conditions. For this aim, each of control and bio-oil modified PF resins was spread on a single bonding surface of the beech veneers with dimensions of $500 \mathrm{~mm} \times 500 \mathrm{~mm} \times 1.5 \mathrm{~mm}$ at the rate of $220 \mathrm{~g} \cdot \mathrm{m}^{-2}$ based on wet mass, using a hand brush. Both surface of the core veneer was glued with the PF resin. Top and bottom veneers were placed with their grain directions perpendicular to the grain direction of core veneer to produce three-layer plywood. The plywood mats were hot pressed under a pressure of $0.2 \mathrm{~N} \cdot \mathrm{mm}^{-2}$ and press temperature of $160^{\circ} \mathrm{C}$ for $6 \mathrm{~min}$. Six different types of plywood panels were produced using the experimental PF resins which were commercial PF resin, lab-made PF resin, and PF resins modified with bio oil of $5,10,15$, and 20 wt\% contents, respectively. The resulting plywood panels were conditioned in a conditioning room having $65 \%$ relative humidity and $23^{\circ} \mathrm{C}$.

\section{Determination of mechanical properties of plywood panels}

Mechanical test specimens were prepared from the conditioned plywood panels according to European (EN) standards. The bending properties of the plywood specimens, three-point bending strength (MOR) and modulus of elasticity (MOE), were determined according to EN 310 (1993) standard. For the determination of bending properties of 6 different types of plywood panels, 20 specimens ( 10 specimens parallel to the plywood face grain and 10 specimens perpendicular to the plywood face grain) from each plywood type, in total 120 specimens, were tested. The tensile shear strength (bond performance) specimens were immersed in boiling water for $4 \mathrm{~h}$, dried in the ventilated drying oven at $60 \pm 3{ }^{\circ} \mathrm{C}$ for $16 \mathrm{~h}$, immersed in boiling water for $4 \mathrm{~h}$, followed by cooling in water at $20 \pm 3^{\circ} \mathrm{C}$ for at least $\mathrm{I} \mathrm{h}$ to decrease the temperature of test specimens to 20 ${ }^{\circ} \mathrm{C}$. The tensile shear strength (parallel direction to the grain of the surface layers) of the conditioned specimens was determined on the universal testing machine (Lloyd instruments, USA) according to class 3: exterior conditions specified in EN 3I4-I (2004) standard. Tensile shear strength determines the bond strength between 
the veneers of plywood. I5 specimens for each type of plywood, in total 90 specimens, were tested for the tensile shear strength of 6 different types of plywood panels.

\section{Statistical analysis}

For each PF resin formulation, one-way analysis of variance, ANOVA, was conducted $(p<0.01)$ to evaluate the effect of bio-oil content in PF resin type on the mechanical properties of plywood panels. Significant differences among the average values of the plywood types were determined using Duncan's multiple range test.

\section{RESULTS AND DISCUSSION}

\section{GC/MS analysis of the bio-oil}

The main peaks identification of compounds was performed by using GC/MS was presented in Figure 2. It was found that the bio-oil was mainly composed of phenolics such as phenol, 3-methyl-phenol, 4-methyl-phenol, 2-methoxyphenol, 2,3-dimethyl-phenol, 2-methoxy-4-methyl-phenol. The high content of phenols could be used as feedstock for chemical synthesis such as adhesive production. Therefore, many researchers focus on pyrolysis to produce phenolic compounds from biomass (OZBAY, 20I5; CHEN et al., 2008; WANG et al., 20I0).

\section{Physical properties of resins}

The physical properties of the control PF resins and bio-oil modified PF resins are given in Table I. The $\mathrm{pH}$ values of the modified resins and the lab PF resin

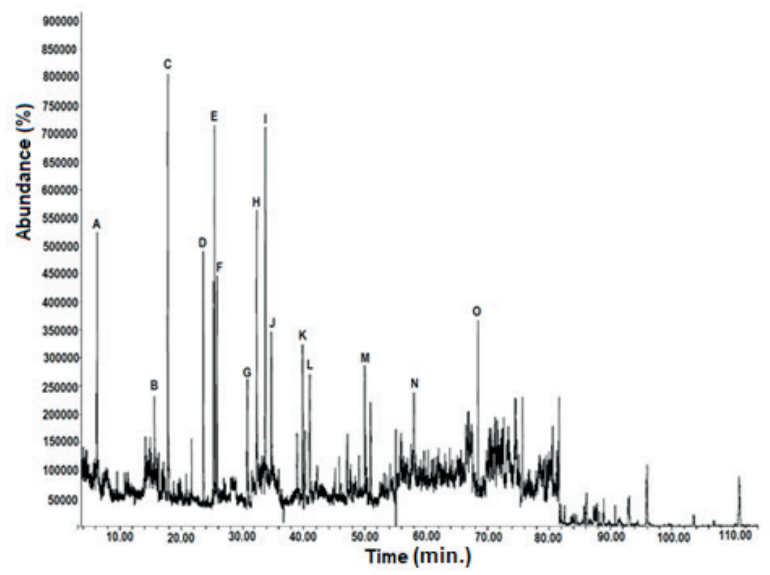

FIGURE $2 \mathrm{GC} / \mathrm{MS}$ chromatogram of the bio-oil obtained from pyrolysis of $500^{\circ} \mathrm{C}$ at a heating rate of $\left.15^{\circ} \mathrm{C} \cdot \mathrm{min}^{-1}\right)(\mathrm{A}$ : furfural, B: 5-methyl-2-furancarboxadehyde, C: phenol, D: 3-methyl-phenol, E: 4-methyl-phenol, F: 2-methoxyphenol, G: 2,3-dimethyl-phenol, $\mathrm{H}$ : naphthalene, I: 2-methoxy-4-methyl-phenol, J: benzenediol). were similar while $\mathrm{pH}$ value of commercial PF resin was lower than all modified resins (Table I). The presence of bio-oil during the synthesis process of a biopolymer clearly affects the viscosity of the resulting resins. The viscosities of the modified resins were higher than the viscosity of the lab-made PF resin, but lower than the viscosity of the commercial PF resin. Some larger molecular compounds from bio-oil may lead to higher viscosity in the bio-oil modified PF resol resins. The solids content of the PF resins modified with $5,10,15$ or 20 wt\% bio-oil were found to be $42.62,42.84,44.14$, and 44.58 wt\%, respectively. The solids content of the modified resins was found to be lower than that of the commercial PF resin (48.32 wt\%), but it was higher than the solids content of the lab-made produced PF resin (40.65 wt\%). Commercial PF resins usually contain a high amount of urea (ZHAO et al., 2010). Urea is the main cause of high solids content.

TABLE I Properties of the unmodified and modified PF resins.

\begin{tabular}{|c|c|c|c|c|}
\hline \multirow[b]{2}{*}{ Type of resin } & \multicolumn{4}{|c|}{ Properties of the PF resins } \\
\hline & $\begin{array}{c}\mathrm{pH} \\
\left(20^{\circ} \mathrm{C}\right)\end{array}$ & $\begin{array}{c}\text { Viscosity } \\
\left(25^{\circ} \mathrm{C}, \mathrm{cps}\right)\end{array}$ & $\begin{array}{c}\text { Solids } \\
\text { content } \\
\text { (\% weight) }\end{array}$ & $\begin{array}{l}\text { Gel time } \\
\text { at } 100^{\circ} \mathrm{C} \\
(\mathrm{s})\end{array}$ \\
\hline Commercial PF resin & $\begin{array}{c}11.00 \\
(0.014)^{\prime}\end{array}$ & 385 (I.I) & $48.32(0.21)$ & $170(0.44)$ \\
\hline Lab-scale PF resin & $\begin{array}{c}11.95 \\
(0.009)\end{array}$ & $205(1.2)$ & $40.65(0.17)$ & $164(0.28)$ \\
\hline PF resin modified with 5 & 11.83 & $354(1.6)$ & $42.62(0.1 \mathrm{I})$ & $156(0.57)$ \\
\hline $\begin{array}{l}\text { wt\% bio oil } \\
\text { PF resin modified with }\end{array}$ & $\begin{array}{l}(0.023) \\
I 1.78\end{array}$ & $364(1.3)$ & $42.84(0.56)$ & | $48(0.34)$ \\
\hline $\begin{array}{l}10 \text { wt\% bio oil } \\
\text { PF resin modified with }\end{array}$ & $\begin{array}{c}(0.014) \\
11.76\end{array}$ & $37 \mid(1.2)$ & $44.14(0.32)$ & $122(0.42)$ \\
\hline $\begin{array}{l}\text { I5 wt\% bio oil } \\
\text { PF resin modified with } \\
20 \text { wt\% bio oil }\end{array}$ & $\begin{array}{c}(0.016) \\
11.64 \\
(0.011)\end{array}$ & $374(1.3)$ & $44.58(0.28)$ & $120(0.53)$ \\
\hline
\end{tabular}

'The values in the parentheses are standard deviations.

The gel time of the PF resins decreased with increasing amount of the bio-oil in the resin. Among the modified resins, the PF resin modified with the 20 wt\% bio-oil had the shortest gel time with a value of $120 \mathrm{~s}$ while the PF resin modified with the $5 \mathrm{wt} \%$ biooil had the longest gel time with a value of I56 s. The gel time of the bio-oil modified resins were shorter than that of the commercial and lab-made resins The gel time values of the lab-made PF resin and commercial PF resin were found to be $164 \mathrm{~s}$ and $170 \mathrm{~s}$, respectively. These findings were similar to the properties of the bio-based PF resins investigated in previous studies (ASLAN et al., 20I5; OZBAY; AYRILMIS, 20I4; ZHAO et al., 20I0; SUKHBAATAR et al., 2009). The bio-based PF resol resins had higher molecular weights, higher polydispersity indices, shorter gel times, and faster curing rates than the lab synthesized control PF resin (ZHAO et al., 20I3). 
A similar behaviour of the bio-oil modified PF resin was observed in this study.

\section{Chemical analysis of resins}

The FT-IR spectra of commercial PF resin, labmade PF resin, and a representative bio-oil modified PF resin are presented in Figure 3. The changes in the functional groups of bio-oil modified PF resins given in the FT-IR spectrum were compared with commercial and lab-made produced PF resins. In the FT-IR spectrum of all the resins, the $\mathrm{O}-\mathrm{H}$ vibrations of hydroxyl groups indicating the presence of aromatics are represented by the absorbance peak between 3500 and $3200 \mathrm{~cm}^{-1}$. The presence of alkanes was shown by the absorbance peak of C-H stretching vibrations between 2900 and 2800 $\mathrm{cm}^{-1}$. An appearance of new bands at around $1650 \mathrm{~cm}^{-1}$ was observed in the resin modified with bio-oil (5-20 wt. \%). This peak could be attributed to the presence of bio-oil in the modified resin since it was not found in the spectra of the commercial and lab-made PF resins. In a previous study, Tejado et al. (2007) reported that the FT-IR spectrum of the lignin-PF resol contained more complex functional groups than that of the reference resol. This may cause the low reactivity or the limited substitution level of phenol.

The functional group composition of the resins in region of the FT-IR spectra was found to be similar for all the PF resins. It could be said that synthesis of bio-oil, phenol, and formaldehyde was successfully performed based on the FT-IR spectrum of the functional groups. In comparison with the commercial PF resin and lab-made PF resin, the bio-oil modified PF resol resins were found to have higher molecular weights, higher viscosities, and shorter gel times. Phenolic compounds of the lignocellulosics can be used used as an accelerator of the PF resin in wood-based panel industry due to its ability to minimize gelation and shorten press time (VÁZQUEZ, 1989; VÁZQUEZ, 2002; TROSA, 200I). Similar results were observed for the phenolic compounds of the bio-oil in this study.

\section{Mechanical properties plywood panels}

The MOR and MOE of the plywood specimens are presented in Table 2. The bending properties of the specimens significantly improved with increasing amount
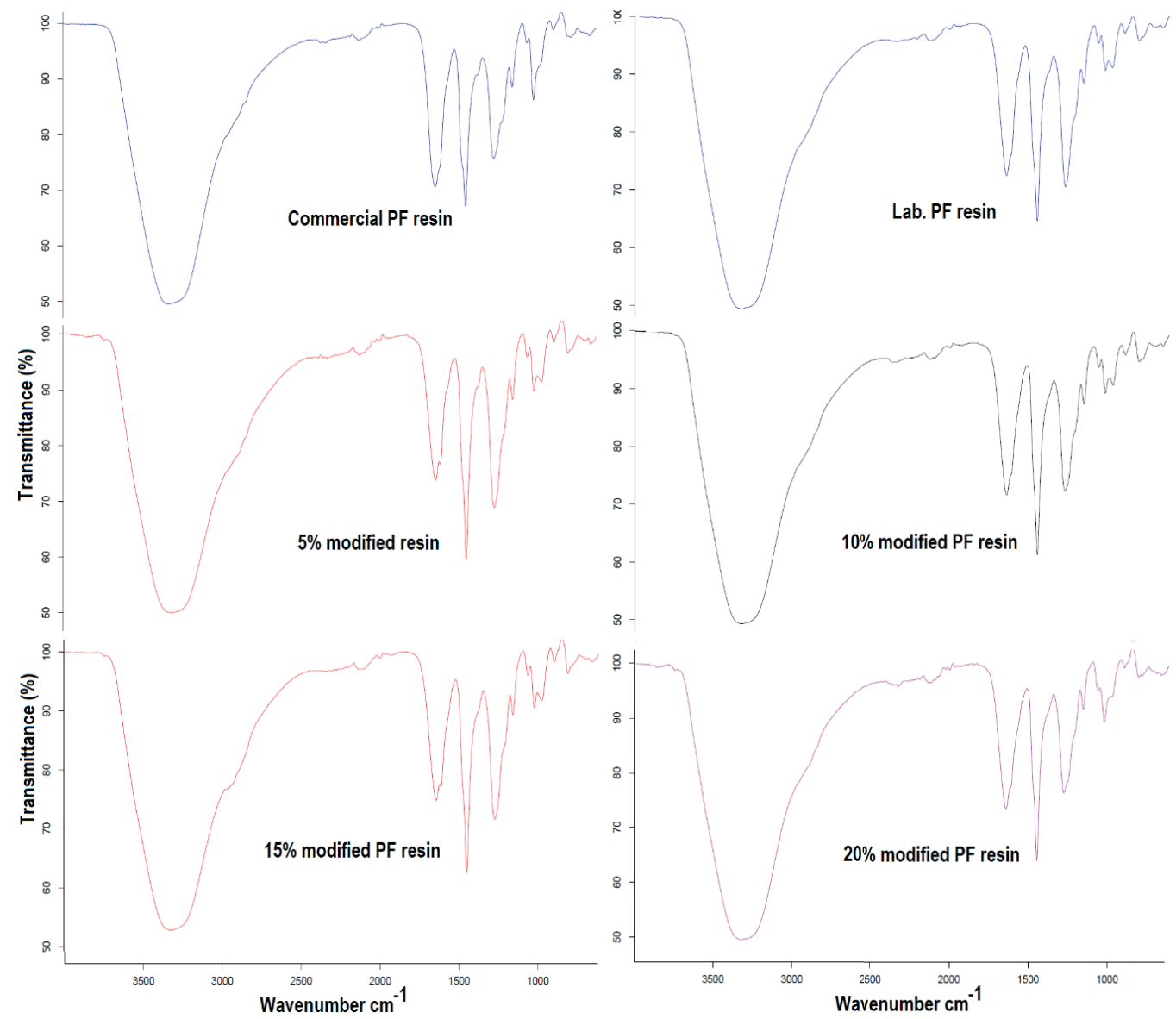

FIGURE 3 FT-IR spectra of PF resins with and without bio-oil. 
of bio-oil in the PF resin up to $20 \mathrm{wt} \%$. Significant differences $(p<0.01)$ were found in the MOR and MOE values of the plywood types. Significant differences were individually determined for these tests by Duncan's multiple comparison tests. The letters in Table 2 show the results of Duncan's multiple range test. The PF resin produced with the bio-oil (5-20 wt\%) had better flexural properties as compared to the commercial and lab-made PF resins. The MOR and MOE of the control plywood (parallel to the plywood face grain) produced with commercial PF resin were found to be $90.4 \mathrm{MPa}$ and $10248 \mathrm{MPa}$, respectively. As the PF resin was produced with $20 \mathrm{wt} \%$ bio-oil, the MOR and MOE values (parallel to the plywood face grain) were found to be $107.3 \mathrm{MPa}$ and $13567 \mathrm{MPa}$, respectively. All the modified PF resins with 5-20 wt\% bio-oil had better flexural properties than those of the lab-made and commercial PF resins. Similar trends were also observed in the MOE values (Table 2). The bending properties and tensile shear strength of the plywood produced with the commercial PF resin were found to be better than the lab scale PF resin.

The wet tensile shear strength results of the plywood specimens produced with the control and modified PF resins are presented in Table 2. The tensile shear strength of the plywood specimens produced with all the modified PF resins were found to be higher than that of the specimens produced with lab-made and commercial PF resins. As the amount of the bio-oil in the PF resin increased from 5 to $20 \mathrm{wt} \%$, the tensile shear strength of the plywood specimens after the pre-treatment increased from 2.18 to $2.50 \mathrm{MPa}$. This property was found to be 2.01 and $2.11 \mathrm{MPa}$ for the plywood specimens produced with the lab-made and commercial PF resins, respectively. The results of the tensile shear strength were found to be above minimum standard requirement (I.0 MPa) of EN 3/4-2 standard for gluing quality of class 3 (exterior conditions) (Table 2). The tensile shear strength of PF resins produced with the bio-oil in this study was found to be higher than that of the commercial PF bonded plywood specimens reported in the literature (AYDIN et al., 2006; BEKHTA et al., 20I4). For example, Bekhta et al. (2014) reported that tensile shear strength (EN 3I4-I method, class 3) of three-layer plywood produced with commercial PF resin with $48.3 \%$ solids content was I.2 MPa. In other study, Aydin et al. (2006) reported that tensile shear strength of three-layer plywood produced from beech wood veneer and PF resin was I.25 MPa. The PF resin produced with the $20 \mathrm{wt} \%$ bio-oil contains lots of hydroxyl methyl and hydrocarbons, which is beneficial to form the crosslinking structure and improved the bonding performance of between the wood veneers. This resulted in better tensile shear strength and bending properties for the plywood specimens.

\section{CONCLUSIONS}

The changes in functional groups of resins were determined according to the results of the FT-IR spectra of modified resins as compared to commercial and labmade PF resin. The FT-IR spectra of the bio-oil modified PF resol resins contained more complex functional groups than those of the control resin. Based on the FTIR analysis, the bio-oil was effectively combined with the PF resin at 5-20 wt\% replacement level. The PF resin produced by substituting up to $20 \mathrm{wt} \%$ of the petroleumbased phenol with the bio-oil showed an improvement in the mechanical properties of the plywood. The bio-oil modified PF resins exhibited better wet bond strength

TABLE 2 Mechanical properties of plywoods produced with unmodified and modified PF resins.

\begin{tabular}{|c|c|c|c|c|c|c|}
\hline \multirow{3}{*}{$\begin{array}{l}\text { Resin type used in the production } \\
\text { plywood code }\end{array}$} & \multirow{3}{*}{$\begin{array}{l}\text { Density } \\
\left(\mathrm{g} \cdot \mathrm{cm}^{-3}\right)\end{array}$} & \multicolumn{5}{|c|}{ Mechanical properties } \\
\hline & & \multicolumn{2}{|c|}{$\begin{array}{l}\text { Modulus of rupture } \\
(\mathrm{MPa})\end{array}$} & \multicolumn{2}{|c|}{$\begin{array}{l}\text { Modulus of elasticity in bending } \\
(\mathrm{MPa})\end{array}$} & \multirow[t]{2}{*}{$\begin{array}{c}\text { Tensile shear strength } \\
\text { (wet) }(\mathrm{MPa})\end{array}$} \\
\hline & & // & $\perp$ & /I & $\perp$ & \\
\hline \multirow{2}{*}{ Commercial PF resin } & 0.77 & 90.4 & 23.0 & 10248 & 1042 & 2.11 \\
\hline & $(0.014)^{\prime}$ & (3.4) $\mathrm{a}^{2}$ & (I.4) ab & (357) a & (75) a & $(0.36) a$ \\
\hline \multirow{2}{*}{ Lab-scale PF resin } & 0.76 & 89.1 & 21.6 & 10017 & 1012 & 2.01 \\
\hline & $(0.010)$ & $(2.8) \mathrm{a}$ & (I.I) ab & $(368) \mathrm{a}$ & $(89) \mathrm{a}$ & $(0.4 I) a$ \\
\hline \multirow{2}{*}{ PF resin modified with $5 \mathrm{wt} \%$ bio oil } & 0.75 & 92.6 & 23.8 & 10567 & 1178 & 2.18 \\
\hline & $(0.013)$ & (2.4) ab & $(0.9) \mathrm{a}$ & (402) a & (79) ab & $(0.34) a$ \\
\hline \multirow{2}{*}{ PF resin modified with 10 wt\% bio oil } & 0.77 & 95.0 & 24.6 & 11374 & 1240 & 2.32 \\
\hline & $(0.012)$ & (3.I) bc & $(1.6) b c$ & (394) a & (97) bc & $(0.1 \mathrm{I}) \mathrm{ab}$ \\
\hline \multirow{2}{*}{ PF resin modified with 15 wt $\%$ bio oil } & 0.76 & 97.9 & 26.1 & 12985 & 1365 & 2.47 \\
\hline & $(0.015)$ & $(2.6) c$ & $(1.2) c$ & $(425)$ bc & $(102) c$ & $(0.22) \mathrm{b}$ \\
\hline \multirow{2}{*}{ PF resin modified with 20 wt $\%$ bio oil } & 0.77 & 107.3 & 29.7 & 13567 & 1596 & 2.50 \\
\hline & $(0.011)$ & $(3.4) d$ & $(I .8) d$ & $(487) \mathrm{c}$ & $(129) d$ & $(0.26) a b$ \\
\hline
\end{tabular}

' The values in the parentheses are standard deviations.

${ }^{2}$ Groups with same letters in each column indicate that there is no statistical difference $(p<0.0 \mathrm{I})$ between the specimens according to Duncan's multiply range test. 
as compared to the commercial and lab-made PF resins. The bio-oil also can be used as accelerators of the PF resins in wood-based panel industry due to its ability to minimize gelation and shorten press time. Exterior grade plywood panels can be successfully produced with PF resin synthesized with $20 \mathrm{wt} \%$ bio oil.

\section{ACKNOWLEDGEMENT}

This work was supported by the Scientific and Technological. Research Council of Turkey (TUBITAK) under Grant I I 50453.

\section{REFERENCES}

ALMA, M.H., BASTURK, M.A., SHIRAISHI, N. Cocondensation of $\mathrm{NaOH}$-catalyzed liquefied wood wastes, phenol, and formaldehyde for the production of resol-type adhesives. Industrial Engineering Chemistry Research, v. 40, p. 5036-5039, $201 \mathrm{I}$.

AMEN-CHEN, C., RIEDL, B., XIANGMING, W., ROY, C. Softwood bark pyrolysis oil-PF resols part I. Resin synthesis and OSB mechanical properties. Holzforschung, v. 56, p. I67-I75, 2002.

ASLAN, M., OZBAY, G., AYRILMIS, N., 20I5. Adhesive characteristics and bonding performance of phenol formaldehyde modified with phenol-rich fraction of crude bio-oil. Journal of Adhesion Science and Technology, v. 29, p. 2679-269I, 2015.

ASTMD I084-08. Standard test methods for viscosity of adhesives. West Conshohocken, PA, ASTM International, 2008.

ASTM D3529M-97. Standard Test Method for Matrix Solids Content and Matrix Content of Composite Prepreg, ASTM International, West Conshohocken, PA, 2008.

AYDIN, I., COLAKOGLU, G., HIZIROGLU, S. Surface characteristics of spruce veneers and shear strength of plywood as a function of log temperature in peeling process International Journal of Solids and Structures, v. 43, p. 6|40-6I47, 2006.

BEKHTA, P., ORTYNSKA, G., SEDLIACIK, J.. Properties of modified phenol-formaldehyde adhesive for plywood panels manufactured from high moisture content veneer. Drvna Industria, v. 65, p. 293-30I, 2014.

CHEN, M., WANG, J., ZHANG, M., CHEN, M., ZHU, X., MIN, F., TAN, Z. Catalytic effects of eight inorganic additives on pyrolysis of pine wood sawdust by microwave heating. Journal of Analytical and Applied Pyrolysis, v. 82, p. |45-I50, 2008.

EN 3 I0. Determination of modulus of elasticity in bending and bending strength, European Committee for Standardization, Brussels, Belgium, 1993.

EN 3|4-I. Plywood - bond quality - test methods. European Committee for Standardization, Brussels, Belgium, 2004.
HIMMELBLAU, D.A., GROZDITS, G.A.. Production of wood composite adhesives with air-blown, fluidized-bed pyrolysis oil. Elsevier Science, Oxford, UK; 1991

JUNMING, X., JIANCHUN, J., WEI, L. Preparation of novolacs using phenolic rich components as partial substitute of phenol from biomass pyrolysis oils. Bulletin of the Chemical Society of Ethiopia, v. 24, p. 25I-257, 2010.

NGO, T.A., KIM, J., KIM, S.S.. Fast pyrolysis of palm kernel cake using a fluidized bed reactor: design of experiment and characteristics of bio-oil. Journal of Industrial Engineering Chemistry, v. 19, p. 137-143, 2013.

OZBAY, G. Catalytic pyrolysis of pine wood sawdust to produce bio-oil: effect of temperature and catalyst additives. Journal of Wood Chemistry and Technology, v. 35, p. 302-3I3, 2015.

OZBAY, G., AYRILMIS, N. Bonding performance of wood bonded with adhesive mixtures composed of phenolformaldehyde and bio-oil. Industrial Crops and Products, v. 66, p. 68-72, 2014.

ROY, C., LIU, X., PAKDEL, H. Process for the production of phenolic-rich pyrolysis oils for use in making phenolformaldehyde resole resins, US Patent 6143856, Pyrovac Technologies Inc., 2000.

SUKHBAATAR, B., STEELE, P.H., INGRAM, L.I., KIM, M.G. Use of lignin separated from bio-oil in oriented strand board binder phenol-formaldehyde resins. Bioresources, v. 4, p. 789-804, 2009.

TEJADO, A., PENA, C., LABIDI, J., ECHEVERRIA, J.M., MONDRAGON, I. Physico-chemical characterization of lignins from deferent sources for use in phenolformaldehyde resin synthesis. Bioresource Technology, v. 98, p. I655-1663, 2007

TROSA, A. A no-aldehyde emission hardener for tannin-based wood adhesives for exterior panels. Holz Als Roh Und Werkstoff, v. 59, p. 266-27I, 200 I.

VÁZQUEZ, G. Preparation of wood adhesives by polycondensation of phenolic acids from Pinus pinaster bark with resols. Holz Als Roh Und Werkstoff, v. 47, p. 49I-494, 1989.

VÁZQUEZ, G. Curing. kinetics of tannin-phenol-formaldehyde adhesives as determined by DSC. Journal of Thermal Analysis and Calorimetry, v. 70, p. 19-28, 2002.

WANG, M., LEITCH, M., XU, C.C. Synthesis of phenolic resol resins using cornstalk-derived bio-oil produced by direct liquefaction in hot-compressed phenol-water. Journal of Industrial Engineering Chemistry, v. I5, p. 870-875, 2009.

WANG, M., WEI, L., ZHAO, T. Cure study of addition-curetype and condensation-addition-type phenolic resins. European Polymer Journal, v. 4I, p. 903-912, 2005.

WANG, W., ZHAO, Z., GAO, Z., GUO, M. Whey proteinbased water resistant and environmentally safe adhesives for plywood. BioResources, 6, 3339-335I, 201 I. 
WANG, Z., WANG, F., CAO, J. Pyrolysis of pine wood in a slowly heating fixed-bed reactor: Potassium carbonate versus calcium hydroxide as a catalyst. Fuel Processing Technology, v. 91, p. 942-950, 2010.

YI, J., ZHANG, J., YAO, S., CHANG, J., LI, B. Preparation of bio-oil-phenol-formaldehyde resins from biomass pyrolysis oil. Applied Mechanics and Materials, v. 174-177, p. |429-|432, 2012.
ZHAO, Y., YAN, N., FENG, M. Characterization of phenolformaldehyde resins derived from liquefied lodgepole pine barks. International Journal of Adhesion and Adhesives, v. 30, p. 689-695, 2010.

ZHAO, Y. Development of bio-based phenol formaldehyde resol resins using mountain pine beetle infested lodgepole pine barks. Ph.D. thesis, University of Toronto, Canada, 2013. 